\title{
Redox variations in the early Ediacaran shallow ocean: evidence from the Doushantuo Formation, South China
}

\author{
ZHEN-BING She ${ }^{1,2}$, AlAGABRi MAJED ${ }^{1}$, LiANGXUAN JiAO ${ }^{1}$ \\ ${ }^{1}$ School of Earth Sciences, China University of Geosciences, Wuhan, \\ 430074, China \\ ${ }^{2}$ State Key Laboratory of Biogeology and Environmental Geology, \\ China University of Geosciences, Wuhan 430074, China
}

The Ediacaran represents a period of fundamental biogeochemical changes that have generally been related to oxygenation of the Earth's atmosphere and oceans. Recent geochemical studies suggest high spatial heterogeneity of oceanic $\mathrm{O}_{2}$ conditions and dynamic marine shelf oxygenation in a dominantly anoxic ocean during the Ediacaran. Here we present mineralogical data from the lower Ediacaran Doushantuo Formation from South China which shed new light on the redox variations of the shallow ocean.

The lower Doushantuo Formation is characterized by glauconitic sandstones and phosphorites deposited in peri-tidal environments. The glaucony minerals mainly occur as interstitial aggregates cementing detrital minerals and phosphatic intraclasts and suggest in situ formation in suboxic pore waters. The glaucony-hosting phosphorites, on the other hand, do not show evident negative $\mathrm{Ce}$ anomalies, consistent with deposition of phosphate precursor in anoxic environment near the sediment/water interface. Moreover, pyrite and marcasite form submillimetersized rosettes, which suggests highly variable pore $\mathrm{pH}$ during early diagenesis. Collectively, the data suggest that the lower Doushantuo Formation deposited in a redox unstable shallow ocean environment. Authigenesis and early diagenetic mineral growth and transformations were controlled by $\mathrm{O}_{2}$ levels and Feredox cycling likely have played key roles in the unprecedented phosphogenic events. 
This abstract is too long to be accepted for publication.

Please revise it so that it fits into the column on one page. 